Jovana Milanovićc ${ }^{*}$, Tijana Lazić ${ }^{2}$, Irena Živković ${ }^{2}$ Milena Milosevićc ${ }^{3}$ Ivona Castvan-Janković ${ }^{4}$, Mirjana Kostić ${ }^{4}$

${ }^{1}$ University of Belgrade, Innovation Center of Faculty of Technology and Metallurgy, Belgrade, Serbia, ${ }^{2}$ University of Arts in Belgrade, Faculty of Applied Arts in Belgrade, Belgrade, Serbia, ${ }^{3}$ University of Belgrade, ICTM, National Institute of the Republic of Serbia, Belgrade, Serbia, ${ }^{4}$ University of Belgrade, Faculty of Technology and Metallurgy, Belgrade, Serbia

Scientific paper

ISSN 0351-9465, E-ISSN 2466-2585

UDC: $677.46: 676.034 .6: 676.017 .66$

https://doi.org/10.5937/zasmat2103180M

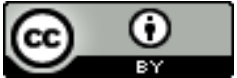

Zastita Materijala $62(3)$

$180-190(2021)$

\title{
Decreasing of water absorptiveness of paper by coating nanofibrillated cellulose films
}

\begin{abstract}
Nanofibrillated films based on TEMPO-oxidized cotton linters were applied to reduce the hydrophilic properties of paper. For this purpose, aqueous dispersions of nanofibrillated cellulose of different composition: 1 and $3 \%$ of nanofibrillated cellulose, up to $13 \%$ of $\mathrm{CaCO}_{3}$ and/or $\mathrm{Al}(\mathrm{OH})_{3}$, up to $20 \%$ of propane-1,2-diol (glycol), and up to $21 \%$ of TEMPO-oxidized cotton linters were coated on the model paper, without additional adhesive. The pristine model paper and papers coated with nanofibrillated cellulose-based composite films were characterized in terms of water absorptiveness by COBB method and water drop contact angle measurements. The surface appearance was characterized by scanning electron microscopy (SEM) and surface chemistry by infrared spectroscopy with Fourier transform and attenuated total reflection (ATR-FTIR). Additionally, optical properties, i.e. measurement of reflection curves and CIE degrees of whiteness, were determined according to appropriate standards. For all papers coated with nanofibrillated cellulose-based films, depending on the composition of the dispersions, a decrease in sorption properties was achieved, without changes in optical properties and surface morphology of the paper compared to the pristine paper.
\end{abstract}

Keywords: Nanofibrillated cellulose films, TEMPO-oxidized cellulose, paper, water absorptiveness, contact angle, optical properties, surface morphology.

\section{INTRODUCTION}

Paper presents the main material for recording cultural achievements all over the world. It is estimated that about 2.5 million kilograms of paper materials are stored in libraries, museums, and archives $[1,2]$. In the composition of the paper, in addition to cellulose, which are present in the largest percentage, there are also lignin and hemicelluloses, and additives, i.e. fillers, sizing agents, pigments, and processing aids [3]. Given the organic origin of the paper, it is vulnerable to the effects of external influences [4], especially regarding humidity and water sorption, and as such it is prone to damage, therefore the protection of documents made on paper materials is necessary. After conservation, when the artworks should be stored in the libraries and archives, it is good that they have less tendency to absorb water.

${ }^{*}$ Corresponding author: Jovana Milanovic

E-mail: jovana@tmf.bg.ac.rs

Paper received: 05. 04. 2021.

Paper accepted: 04. 06. 2021.

Paper is available on the website: www.idk.org.rs/journal
Additionally, water causes damage to paper during natural aging processes [5]. The protection and preservation of documents made on paper materials is a necessary work for libraries and archives, which are the guardians of the evolution of philosophical and scientific thinking in the development of human history $[2,6]$.

In addition to the use of nano- and microfibrillated cellulose for the paper stabilization [4,713], which have also been applied in our previous work [14], materials based on nano- and microcellulose can also be used to reduce the hydrophilic properties of paper. For this purpose, in this paper, aqueous dispersions of nanofibrillated cellulose of different composition: 1 and $3 \%$ of nanofibrillated cellulose, up to $13 \%$ of $\mathrm{CaCO}_{3}$ and/or $\mathrm{Al}(\mathrm{OH})_{3}$, up to $20 \%$ of propane-1,2-diol (glycol), and up to $21 \%$ of TEMPO-oxidized cotton linters were coated on the model paper with a grammage of $200 \mathrm{~g} / \mathrm{m}^{2}$, without additional adhesive.

Nanocellulose dispersions were obtained by ultrasound disintegration[15] of the previously TEMPO-oxidized cotton linters [16-18]. As it is known, during TEMPO-mediated oxidation, the 
nitroxyl radical affects the oxidation from the alcohol to the aldehyde groups, while the hypobromite, generated in situ from hypochlorite and bromide, performs the further oxidation of the aldehyde to the carboxyl groups [19-24]. As a result of the introduction of negatively charged $\mathrm{COO}^{-}$groups, the aggregation of fibrils via electrostatic repulsion is disabled, which facilitates fibrillation during mechanical disintegration $[20,25]$ (Figure 1).

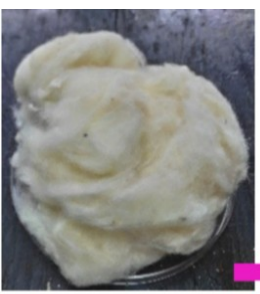

Pristine cotton fibers

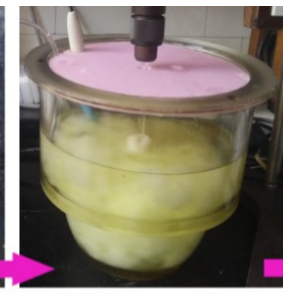

oxidation
ox

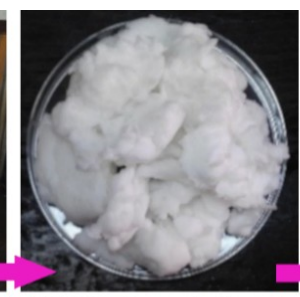

EMPO-oxidized

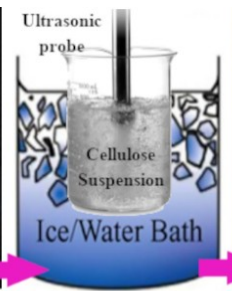
Ultra-
sonification

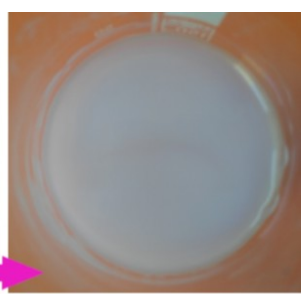

Nano-cellulose dispersion

Figure 1. The main steps in obtaining nanocellulose dispersions from TEMPO-oxidized cotton

\section{Slika 1. Faze dobijanja nanoceluloznih disperzija od TEMPO-oksidisanog pamuka}

The pristine model paper and papers coated with nanofibrillated cellulose-based composite films were characterized in terms of water absorptiveness by COBB method and water drop contact angle measurements. The surface appearance was characterized by scanning electron microscopy (SEM) and surface chemistry by infrared spectroscopy with Fourier transform and attenuated total reflection (ATR-FTIR). Additionally, optical properties, i.e. measurement of reflection curves and $\mathrm{CIE}$ degrees of whiteness, were determined according to appropriate standards.

\section{MATERIALS AND METHODS}

\subsection{Materials}

a) Model papers: Fabriano Watercolor by Fedrigoni Spa, Italy, $200 \mathrm{~g} / \mathrm{m}^{2}\left(\mathrm{FW}_{200}\right)$

b) Cotton linters with $0.0063 \mathrm{mmol} \mathrm{CHO}$ groups $/ \mathrm{g}$ fibers and $0.0401 \mathrm{mmol} \mathrm{COOH}$ groups $/ \mathrm{g}$ fibers, obtained from the company "Viskoza a.d." Loznica, Serbia, were used for TEMPOmediated oxidation.

c) All applied chemicals were p.a. grade, used without further purification, and obtained from commercial sources.

\subsection{Methods}

a) Obtaining of TEMPO-oxidized cellulose (TOC) The TEMPO-mediated oxidation was applied for cellulose oxidation. TEMPO/ $\mathrm{NaBr} / \mathrm{NaClO}$ oxidation was carried out according to the literature [18], [26,27]. Cotton linters (10 g) were suspended in water $(750 \mathrm{ml})$ containing $0.050 \mathrm{~g}$ TEMPO $\left(\mathrm{C}_{9} \mathrm{H}_{18} \mathrm{NO}, 98 \%\right.$, "Aldrich", Germany) and $0.50 \mathrm{~g}$ sodium bromide ( $\mathrm{NaBr}, \mathrm{M}=102.89 \mathrm{~g} / \mathrm{mol}$, "Acros", Organics, USA). Subsequently, the designed amount of $12 \%$ available chlorine $\mathrm{NaClO}$ solution
( $\mathrm{NaOCl}, \mathrm{M}=74.44 \mathrm{~g} / \mathrm{mol}$, "Acros", Organics, USA), corresponding to $12 \mathrm{mmol} / \mathrm{g}$ cellulose, whose $\mathrm{pH}$ had previously been adjusted to 10.55 , was added to the mixture under continuous stirring. The reaction rate was then monitored by the consumption of a solution of $0.5 \mathrm{M} \mathrm{NaOH}(\mathrm{NaOH}$, $\mathrm{M}=40.00 \mathrm{~g} / \mathrm{mol}$, "Lachema, Czech Republic) while maintaining the $\mathrm{pH}$ of the slurry at 10.55 at room temperature for $3 \mathrm{~h}$. In this experiments, the opensource $\mathrm{pH}$-stat was used to maintain the $\mathrm{pH}$ value during the oxidative process and prevent undesirable side effects that can occur at lower $\mathrm{pH}$ (i.e. hypochlorite becomes an overly aggressive and non-selective oxidant, and also TEMPO reactivity is decreased $[16,18,28]$. After stirring within the designated time, the oxidation was quenched by adding ethanol (ca. $5 \mathrm{ml}, \mathrm{C}_{2} \mathrm{H}_{5} \mathrm{OH}, 95$ $\%, M=46.07 \mathrm{~g} / \mathrm{mol}$, "Zorka Pharma" a. d. Sabac, Serbia). The oxidized cellulose was washed thoroughly with water and then ethanol on filter paper that was placed in the Büchner funnel. The resultants were stored as a never-dried state at $5^{\circ} \mathrm{C}$.

\section{b) Obtaining nanofibrillated cellulose (NFC)}

Nanofibrillated cellulose was obtained by further exposed of TEMPO-oxidized cotton linters to ultrasonic disintegration, according to the procedure given in the literature [15]. In this paper, the $1 \%$ and $3 \%$ of nanofibrillated cellulose dispersions were prepared and applied (See figure 1 in the Introduction).

c) Characterization of obtained nanofibrillated cellulose (NFC)

The topographical features of the surfaces of nanofibrillated cotton linters, were characterized by AFM in tapping mode with an Agilent 5500 AFM multimode scanning probe microscope (Digital Instruments, Santa Barbara, CA). The images were scanned using silicon cantilevers (ATEC-NC, 
Nanosensors, Germany), with a resonance frequency of $210-490 \mathrm{kHz}$ and a force constant of 12-110 $\mathrm{N} \mathrm{m}^{-1}$. All measurements were performed at ambient temperature in the air. All images were recorded with a resolution of $2048 \times 2048$ pixels and were processed using the freeware Gwyddion. d) Obtaining of dispersions for coating paper

Seven types of gel-like dispersions were obtained by the combination of nanofibrillated cotton linters dispersions with aluminum-hydroxide $(\mathrm{ATH})$, calcium carbonate $\left(\mathrm{CaCO}_{3}\right)$, propane-1,2diol (glycol), and TOC, as it is shown in table 1.

Table 1. Sample marks and scheme of a combination of $\mathrm{ATH}, \mathrm{CaCO}_{3}$, glycol, and TEMPO-oxidized cotton linters in seven types of gel-like dispersions

Tabela 1. Oznake uzoraka i prikaz načina kombinovanja $\mathrm{ATH}, \mathrm{CaCO}_{3}$, glikola i TEMPO-oksidisanog pamučnog lintersa u sedam disperzija na bazi nanoceluloze

\begin{tabular}{|c|c|c|c|c|c|c|c|c|c|}
\hline \multirow{2}{*}{\multicolumn{2}{|c|}{$\begin{array}{l}\text { Components in } \\
\text { dispersions }\end{array}$}} & \multicolumn{8}{|c|}{ Sample marks } \\
\hline & & $\mathrm{FW}_{200}$ & $1 F W_{200}$ & $2 \mathrm{FW}_{200}$ & $3 \mathrm{FW}_{200}$ & $4 \mathrm{FW}_{200}$ & $5 \mathrm{FW}_{200}$ & $6 \mathrm{FW}_{200}$ & $7 \mathrm{FW}_{200}$ \\
\hline \multirow{2}{*}{ NFC } & $1 \%$ & - & 66.7 & 52.6 & - & 66.7 & 52.6 & - & - \\
\hline & $3 \%$ & - & - & - & 66.7 & - & - & 66.7 & 66.7 \\
\hline \multicolumn{2}{|l|}{ ATH } & - & 13.3 & 10.5 & 13.3 & - & - & - & 6.65 \\
\hline \multicolumn{2}{|l|}{$\mathrm{CaCO}_{3}$} & - & - & - & - & 13.3 & 10.5 & 13.3 & 6.65 \\
\hline \multicolumn{2}{|l|}{ Glycol } & - & 20.0 & 15.8 & 20.0 & 20.0 & 15.8 & 20.0 & 20.0 \\
\hline \multicolumn{2}{|l|}{ TOC } & - & - & 21.1 & - & - & 21.1 & - & - \\
\hline \multicolumn{2}{|c|}{ Dispersions: } & - & $\begin{array}{c}1 \% \text { NFC } \\
+ \text { ATH } \\
+ \text { glycol }\end{array}$ & $\begin{array}{l}\text { 1\%NFC } \\
+ \text { ATH } \\
\text { +glycol } \\
+ \text { TOC }\end{array}$ & $\begin{array}{c}3 \% \mathrm{NFC} \\
+\mathrm{ATH}+ \\
\text { glycol }\end{array}$ & $\begin{array}{c}1 \% \mathrm{NFC}+ \\
\mathrm{CaCO}_{3}+ \\
\text { glycol }\end{array}$ & $\begin{array}{c}1 \% \mathrm{NFC} \\
+\mathrm{CaCO}_{3} \\
+ \text { glycol } \\
+\mathrm{TOC}\end{array}$ & $\begin{array}{c}3 \% \mathrm{NFC}+ \\
\mathrm{CaCO}_{3}+ \\
\text { glycol }\end{array}$ & $\begin{array}{c}3 \% \mathrm{NFC}+ \\
\text { ATH } \\
+\mathrm{CaCO}_{3} \\
+ \text { glycol }\end{array}$ \\
\hline
\end{tabular}

e) Coating of the model papers with nanocellulose dispersions

The $0.020 \mathrm{ml} / \mathrm{cm}^{2}$ NFC dispersions were applied to the model paper with a brush applicator, on both sides of the paper (front and backside). After application of dispersions on the paper, the samples were dried at $30{ }^{\circ} \mathrm{C}$ and used for further analysis.

f) Determination of water absorptiveness - COBB method

The water absorptiveness of the pristine and models papers with applied nanocellulose dispersions was determined according to the COBB method, according to the standard SRPS EN ISO 535: 2014.

\section{g) Determination of contact angle}

The wettability of the pristine and model papers was studied by water drop contact angle measurements. Water droplets were photographed using the macro mode of a mobile phone camera (Redmi Note 8Pro) and the obtained images were subsequently analyzed using ImageJ software with Low Bond Axisymmetric Drop Shape Analysis plug-in [29, 30].

\section{h) Determination of optical properties}

Color CIE $L^{*} a^{*} b^{*}$ coordinates of the unmodified, paper coated with different nanocellulose dispersions were determined with Datacolor SF300 spectrophotometer under illuminant D65 using the $10^{\circ}$ standard observer. Reported values are the mean values of three determinations of $L^{*}, a^{*}, b^{*}$ coordinates per sample. Color differences $\left(\Delta E^{*}\right)$, which are very important to evaluate relationships between visual and numerical analyses, are calculated as the Euclidean distance between two points in the three-dimensional space defined by $L^{*}, \quad a^{*}, \quad b^{*}: \Delta E^{*}=\sqrt{\left(\Delta a^{*}\right)^{2}+\left(\Delta b^{*}\right)^{2}+\left(\Delta L^{*}\right)^{2}}$, where $\Delta L^{*}$ is the color lightness difference between two points, $\Delta a^{*}$ is the red/green difference between two points, and $\Delta b^{*}$ is the yellow/blue difference between the two points. The color difference was determined between unmodified paper $\left(\mathrm{FW}_{200}\right)$ and papers coated with different dispersions, Table 1 . The reflectance values and the CIE whiteness index were determined according to the standard SRPS ISO 11476:2014.

i) SEM observing of surface morphology:

The surface morphology of unmodified and coated papers was observed by a Field Emission Scanning Electron Microscopy (FESEM, TescanMIRA $3 \mathrm{XMU}$ ) at $20 \mathrm{kV}$. The samples were sputter-coated with $\mathrm{Au} / \mathrm{Pd}$ alloy before analysis (Polaron SC502, Fison Instruments, UK).

j) Attenuated total reflection Fourier transform infrared spectroscopy (ATR-FTIR) for structural analysis

The structural analysis of the samples was performed by Fourier-Transfer Infrared 
Spectroscopy (FTIR) using a Nicolet ${ }^{\mathrm{TM}}$ is $^{\mathrm{TM}} 10$ FTIR Spectrometer (Thermo Fisher Scientific) Attenuated Total Reflectance (ATR). The spectra were recorded in the range $4000-500 \mathrm{~cm}^{-1}$ with a resolution of $4 \mathrm{~cm}^{-1}$, and room temperature, in 20 scan modes. The spectrometer was equipped with OMNIC software and recorded the spectra in the wavelength range from 2.5 to $20 \mu \mathrm{m}$ (i.e. from 4000 $\mathrm{cm}^{-1}$ to $500 \mathrm{~cm}^{-1}$ ). Before ATR-FTIR measurements, samples were dried overnight at $40^{\circ} \mathrm{C}$ and stored in the desiccator until the measurements.

\section{RESULTS AND DISCUSSION}

a) Surface morphology of nanofibrillated cellulose (NFC) obtained from TEMPO-oxidized cotton linters

According to the literature [21], the high amount of introduced anionic carboxyl groups in oxidized fibers, i.e. $0.1171 \mathrm{mmol} \mathrm{CHO}$ groups $/ \mathrm{g}$ fibers and $0.9291 \mathrm{mmol} \mathrm{COOH} / \mathrm{g}$ fibers [14], present the key factor that influences the process of ultrasonic defibrillation. The surface morphology of nanofibrillated cellulose, obtained after ultrasonic defibrillation, is shown in figure 2. The AFM image shows typical rod-like crystals of nano-fibers with crosssections in the nanometer range, which is in agreement with literature data $[14,15,21]$.

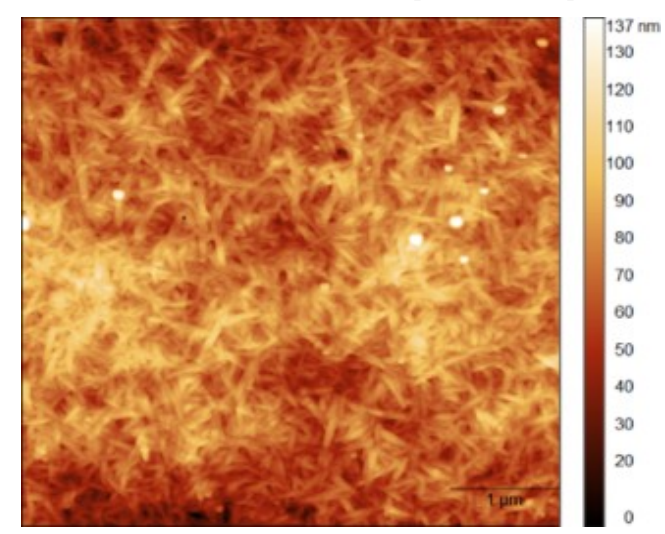

Figure 2. AFM image of the topographical features of nano-fibers obtained by ultrasonic disintegration of TEMPO-oxidized cotton linters, 1000 times diluted (Topography: $5.0 \mu \mathrm{m} \times 5.0 \mu \mathrm{m}$ )

Slika 2. AFM snimak nano vlakana dobijenih ultrazvučnim dispergovanjem TEMPO-oksidisanog pamučnog lintersa, razblaženje 1000 puta (dimenzije 5,0 $\mu \mathrm{m} \times$ 5,0 $\mu \mathrm{m}$ )

a) Water absorptiveness of pristine and coated papers (COBB method) and determination of contact angle

Figure 3. shows the results obtained for the water absorptiveness, for both, front and back sides of the pristine paper and model papers coated with nanofibrillated cellulose films. The pristine paper water absorptiveness was $42.73 \%$ for the front side, and $43.39 \%$ for the backside of the paper. For this sample determined contact angle was $44.89^{\circ}$ and $48,702^{\circ}$ for the front and backside of the paper, respectively. For all coated paper a decrease in water absorptiveness was obtained in the range from 0.7 to $26.8 \%$, with an increase for contact angle values from $55.22^{\circ}$ to $83.17^{\circ}$, depending on the composition of the coated nanocellulose dispersion (Table 2). Images of the determined contact angle for the set of coated paper are shown in figure 4.The largest difference in the decrease in water sorption (1.43 times lower) was obtained for model paper coated with the dispersion 2, i.e.: $1 \%$ NFC $(52.6 \%)+$ ATH $(10.5 \%)+$ glycol $(15.8 \%)$, on the backside of the paper. For the same coated model paper the maximal increase in contact angle value was also determined $\left(83.17^{\circ}\right)$. Different results of sorption properties for the front and backside of the paper are the consequence of the result of the production process. According to the literature [14], no matter how fine the sieve is, it leaves an imprint on the paper surface in contact resulting in different roughness of two paper sides. The last one affects water absorption which is highly dependent on the surface roughness.

Taking into account that once when the conservation of the artworks is finished and they are stored in the libraries and archives, it is better if they have less tendency to absorb water [5]. Since the fact that water causes damage to paper during natural aging processes, the obtained results can be used to adjust the hydrophilic surface of the documents and artworks on the paper.

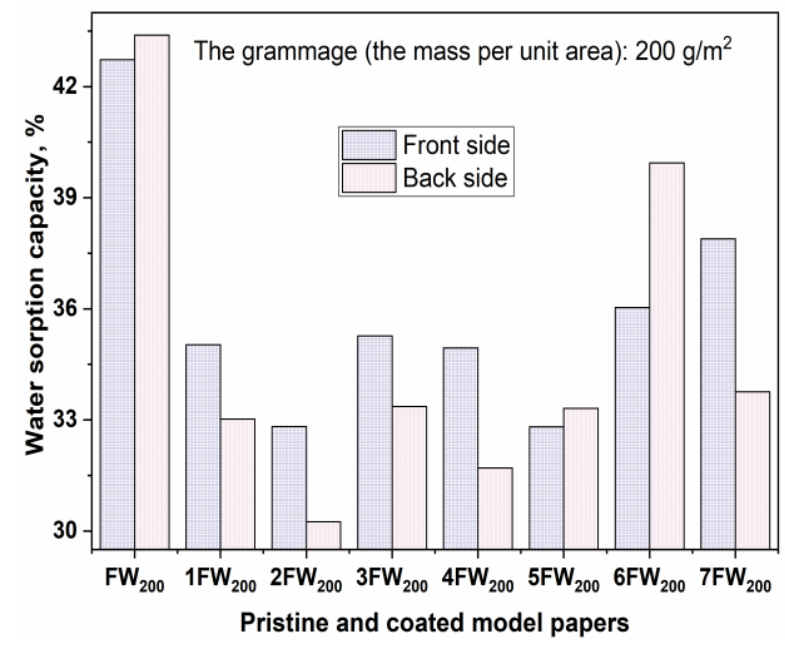

Figure 3. Water absorptiveness (\%) of pristine model paper $F W_{200}$ and coated model papers with different nanofibrillated cellulose films

Slika 3. Sposobnost upijanja vode (\%) nemodifikovanog model papira $F W_{200}$ i model papira oslojenih nanoceluloznim filmovima različitog sastava 
Table 2. Sample marks and contact angle for the pristine and the NFC coated model papers

Tabela 2. Oznake uzoraka i ugao kvašenja nemodifikovanog model papira $F W_{200}$ i model papira oslojenih nanoceluloznim filmovima različitog sastava

\begin{tabular}{|c|c|c|c|c|}
\hline \multirow{3}{*}{ Sample marks } & \multirow{2}{*}{\multicolumn{2}{|c|}{$\frac{\text { Front side of paper }}{\text { Contact angle }^{\circ}}$}} & \multicolumn{2}{|c|}{ Backside of paper } \\
\hline & & & & \\
\hline & $\mathrm{L}$ & $\mathrm{R}$ & $\mathrm{L}$ & $\mathrm{R}$ \\
\hline $\mathrm{FW}_{200}$ & 44.86 & 44.92 & 48.57 & 48.84 \\
\hline $1 \mathrm{FW}_{200}$ & 72.92 & 72.95 & 70.24 & 70.58 \\
\hline $2 \mathrm{FW}_{200}$ & 80.58 & 81.82 & 83.06 & 83.17 \\
\hline $3 \mathrm{FW}_{200}$ & 73.32 & 73.62 & 69.12 & 68.95 \\
\hline $4 \mathrm{FW}_{200}$ & 70.66 & 70.36 & 78.47 & 77.86 \\
\hline $5 \mathrm{FW}_{200}$ & 79.40 & 79.83 & 69.25 & 69.82 \\
\hline $6 \mathrm{FW}_{200}$ & 61.63 & 61.48 & 55.22 & 55.36 \\
\hline $7 \mathrm{FW}_{200}$ & 61.94 & 61.33 & 68.54 & 67.96 \\
\hline
\end{tabular}

Sample The front side of the paper
FW $_{200}$
FWW $_{200}$
$\mathrm{FW}_{200}$
$6 \mathrm{FW}$
200

Figure 4. Images of determined contact angle for the pristine model paper $F W_{200}$ and set of the coated model papers with different nanofibrillated cellulose films (samples: $1 F W_{200}, 2 F W_{200}$, and $6 F W_{200}$ )

Slika 4. Fotografije određivanja ugla kvašenja nemodifikovanog model papira $F W_{200}$ i model papira oslojenih nanoceluloznim filmovima različitog sastava (uzorci: $1 F W_{200}, 2 F W_{200}$, and $6 F W_{200}$ )

b) Optical properties of pristine paper and model papers coated with different nanofibrillated cellulose films

The success of the development of the methods in the field of application related to documents and artworks on paper, such as strengthening the mechanical properties or reduction of the hydrophilic properties of paper, is highly dependent on the fact that they do not adversely affect the optical properties of the paper [31], that present one of the most important paper characteristics from the practical point of view [4]. With colorimetric measurements, the uniformity of samples can be objectively evaluated and presented as $L^{*}, a^{*}, b^{*}$ coordinates named by CIE $L^{*} a^{*} b^{*}$ color space values. CIE $L a b$ values, as well as $\Delta L^{*}, \Delta a^{*}, \Delta b^{*}$, and $\Delta E^{*}$ values, determined as a difference between corresponding data for the coated model paper and the pristine model paper are presented for the front and the backside of paper in Tables 3 and 4. 
Table 3. The colorimetric data $L^{*}, a^{*}, b^{*}, C^{*}$, and $h$ value for the pristine paper $F W_{200}$ and coated model papers with different nanofibrillated cellulose films for the front side of the paper. $\Delta L^{*} \Delta a^{*}, \Delta b^{*}$, and $\Delta E^{*}$ values were determined as a difference between corresponding data of coated and pristine paper

Tabela 3. Kolorimetrijski podaci: $L^{*}, a^{*}, b^{*}, C^{*} i$ vrednost lica nemodifikovanog model papira $F W_{200} i$ model papira oslojenih nanoceluloznim filmovima različitog sastava. Vrednosti: $\Delta L^{*} \Delta a^{*}, \Delta b^{*} i \Delta E^{*}$ izračunate su kao razlika između odgovarajućih podataka za naslojene papire i nemodifikovanog papira

\begin{tabular}{|c|c|c|c|c|c|c|c|c|c|c|c|}
\hline The front side & $\mathrm{L}^{*}$ & $\mathrm{a}^{*}$ & $\mathrm{~b}^{*}$ & $\mathrm{C}^{*}$ & $\mathrm{~h}$ & $\Delta \mathrm{L}^{*}$ & $\Delta \mathrm{a}^{*}$ & $\Delta \mathrm{b}^{*}$ & $\Delta \mathrm{C}^{*}$ & $\Delta \mathrm{H}^{*}$ & $\Delta \mathrm{E}^{*}$ \\
\hline $\mathrm{FW}_{200}$ & 95.83 & 0.18 & 2.63 & 2.66 & 86.16 & - & - & - & - & - & - \\
\hline 1FW $_{200}$ & 95.49 & 0.13 & 2.86 & 2.89 & 87.36 & -0.34 & -0.05 & 0.23 & 0.22 & 0.06 & 0.42 \\
\hline $2 \mathrm{FW}_{200}$ & 95.66 & 0.16 & 2.76 & 2.78 & 86.64 & -0.17 & -0.02 & 0.13 & 0.12 & 0.02 & 0.21 \\
\hline $3 \mathrm{FW}_{200}$ & 95.67 & 0.14 & 2.68 & 2.70 & 86.96 & -0.15 & -0.04 & 0.04 & 0.05 & 0.04 & 0.17 \\
\hline $4 \mathrm{FW}_{200}$ & 95.71 & 0.19 & 2.70 & 2.73 & 85.98 & -0.12 & 0.01 & 0.07 & 0.08 & -0.01 & 0.14 \\
\hline $5 \mathrm{FW}_{200}$ & 95.43 & 0.21 & 2.73 & 2.76 & 85.60 & -0.40 & 0.04 & 0.10 & 0.10 & -0.03 & 0.42 \\
\hline $6 \mathrm{FW}_{200}$ & 95.57 & 0.20 & 2.63 & 2.65 & 85.65 & -0.26 & 0.02 & 0.00 & 0.00 & -0.02 & 0.26 \\
\hline 7FW $_{200}$ & 95.69 & 0.16 & 2.63 & 2.65 & 86.39 & -0.14 & -0.01 & -0.01 & -0.01 & 0.01 & 0.14 \\
\hline
\end{tabular}

Table 4. The colorimetric data $L^{*}, a^{*}, b^{*}, C^{*}$, and $h$ value for the pristine paper $F W_{200}$ and coated model papers with different nanofibrillated cellulose films for the backside of the paper. $\Delta L^{*} \Delta a^{*}, \Delta b^{*}$, and $\Delta E^{*}$ values were determined as a difference between corresponding data of coated and pristine paper

Tabela 4. Kolorimetrijski podaci: $L^{*}, a^{*}, b^{*}, C^{*} i$ h vrednost naličja nemodifikovanog model papira $F W_{200} i$ model papira oslojenih nanoceluloznim filmovima različitog sastava. Vrednosti: $\Delta L^{*} \Delta a^{*}, \Delta b^{*} i \Delta E^{*}$ izračunate su kao razlika između odgovarajućih podataka za naslojene papire i nemodifikovanog papira

\begin{tabular}{|c|c|c|c|c|c|c|c|c|c|c|c|}
\hline The backside & $L^{*}$ & $a^{*}$ & $b^{*}$ & $C^{*}$ & $\mathrm{~h}$ & $\Delta \mathrm{L}^{*}$ & $\Delta \mathrm{a}^{*}$ & $\Delta b^{*}$ & $\Delta C^{*}$ & $\Delta \mathrm{H}^{*}$ & $\Delta \mathrm{E}^{*}$ \\
\hline $\mathrm{FW}_{200}$ & 95.84 & 0.24 & 2.47 & 2.51 & 84.43 & - & - & - & - & - & - \\
\hline $1 \mathrm{FW}_{200}$ & 95.72 & 0.16 & 2.52 & 2.55 & 86.42 & -0.13 & -0.08 & 0.05 & 0.04 & 0.09 & 0.16 \\
\hline $2 \mathrm{FW}_{200}$ & 95.70 & 0.16 & 2.55 & 2.57 & 86.42 & -0.14 & -0.08 & 0.07 & 0.06 & 0.09 & 0.18 \\
\hline $3 \mathrm{FW}_{200}$ & 95.82 & 0.12 & 2.56 & 2.59 & 87.29 & -0.02 & -0.13 & 0.09 & 0.08 & 0.13 & 0.15 \\
\hline $4 \mathrm{FW}_{200}$ & 95.81 & 0.15 & 2.61 & 2.63 & 86.62 & -0.03 & -0.09 & 0.13 & 0.12 & 0.10 & 0.17 \\
\hline $5 \mathrm{FW}_{200}$ & 95.67 & 0.17 & 2.62 & 2.65 & 86.16 & -0.31 & -0.07 & 0.14 & 0.14 & 0.08 & 0.23 \\
\hline $6 \mathrm{FW}_{200}$ & 95.74 & 0.15 & 2.53 & 2.56 & 86.59 & -0.10 & -0.09 & 0.06 & 0.05 & 0.09 & 0.15 \\
\hline $7 \mathrm{FW}_{200}$ & 95.81 & 0.13 & 2.60 & 2.62 & 86.98 & -0.03 & -0.11 & 0.12 & 0.12 & 0.11 & 0.17 \\
\hline
\end{tabular}

Table 5. CIE whiteness index and D65 brightness determined for pristine model paper $F W_{200}$ and model papers coated with different nanofibrillated cellulose films, for front and backside of the paper

Tabela 5. CIE stepen beline i D65 svetlina određena za lice i naličje nemodifikovanog model papira $F W_{200}$ i model papira oslojenih nanoceluloznim filmovima različitog sastava

\begin{tabular}{|c|c|c|c|c|}
\hline \multirow{2}{*}{ Paper marks } & \multicolumn{2}{|c|}{ The front side of the paper } & \multicolumn{2}{c|}{ The backside of the paper } \\
\cline { 2 - 5 } & CIE Whiteness index & D65 Brightness & CIE Whiteness index & D65 Brightness \\
\hline $\mathrm{FW}_{200}$ & 78.07 & 85.13 & 78.83 & 86.29 \\
\hline 1FW $_{200}$ & 76.27 & 85.22 & 78.27 & 86.15 \\
\hline $2 \mathrm{FW}_{200}$ & 77.11 & 85.73 & 78.14 & 86.06 \\
\hline $3 \mathrm{FW}_{200}$ & 77.47 & 85.87 & 78.34 & 86.34 \\
\hline $4 \mathrm{FW}_{200}$ & 77.48 & 85.91 & 78.15 & 86.28 \\
\hline $5 \mathrm{FW}_{200}$ & 76.74 & 85.24 & 77.78 & 85.94 \\
\hline $6 \mathrm{FW}_{200}$ & 77.56 & 85.69 & 78.31 & 86.18 \\
\hline $7 \mathrm{FW}_{200}$ & 77.69 & 85.94 & 78.20 & 86.27 \\
\hline
\end{tabular}


Based on our previous experience [14], the expected result was that the applied nanofibrillated cellulose films did not cause a color change of coated paper compared to the color of the pristine model paper. The results were confirmed by the determination of CIE whiteness index, D65 brightness (Table 5), and $\Delta E^{*}$ values, which in the case of model paper of $200 \mathrm{~g} / \mathrm{m}^{2}$, were in the range from 0.14 to 0.42 . Practically, values of $\Delta E^{*}$ that are lower than one, could not be visually detected by human eyes. Besides that, the results obtained for reflectance measurement for the visible region of the spectra, show only minor differences between the reflectance of coated model papers and pristine model paper, for both the front and backside of papers (Figure 5).
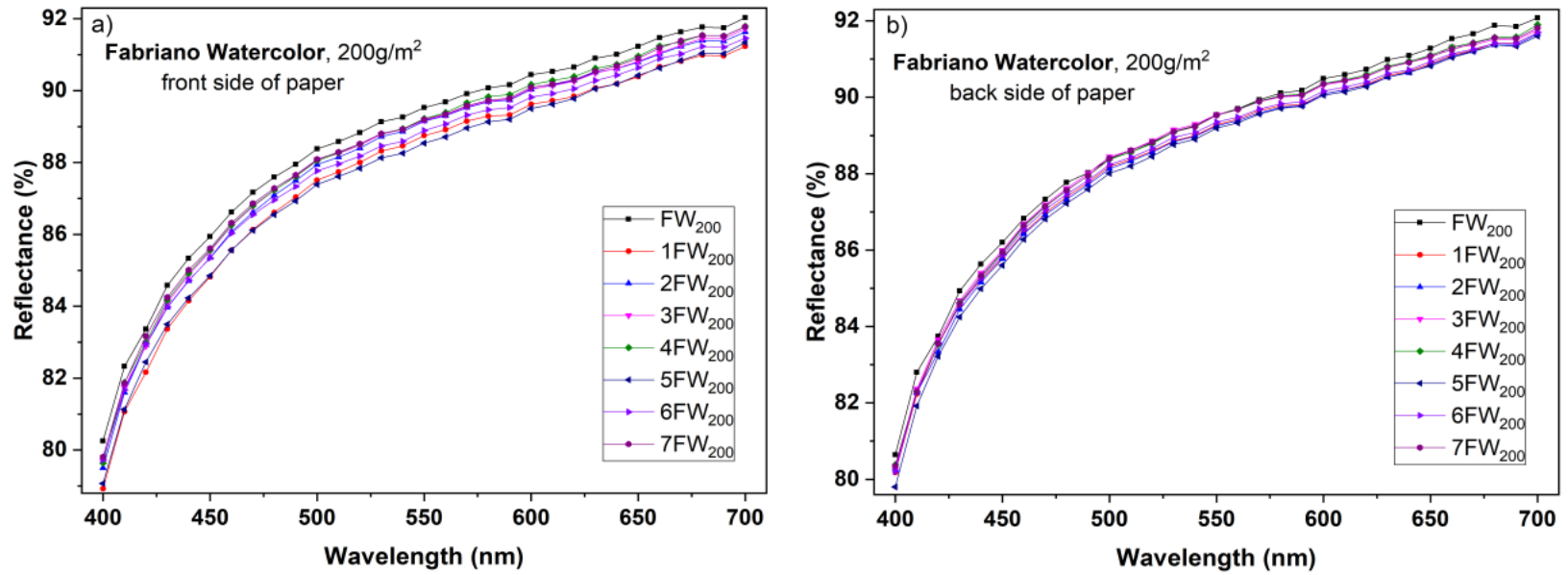

Figure 5. Reflectance (\%) of pristine model paper FW 200 and coated model papers with different nanofibrillated cellulose films for a) front and b) backside of the paper

Slika 5. Krive refleksije (\%) a) lica i b) naličja nemodifikovanog model papira $F_{200}$ i model papira oslojenih nanoceluloznim filmovima različitog sastava

c) The effect of the coating on the structure and chemistry of the paper surface

The structure analysis of the paper surface showed that there is no noticeable difference between the morphology of pristine paper $\left(\mathrm{FW}_{200}\right)$ and model papers coated with nanofibrillated cellulose films (Figure 6). Additionally, as can be seen on SEM images, the different compositions of the dispersions did not affect the appearance of the paper surface. The reason for this is probably because the chemical composition of the paper itself[3] is similar to the composition of nanofibrillated cellulose films, with added fillers and plasticizers (Table 1) that are used for coated on the front and backside of the papers.

The surface chemistry of the paper was monitored by ATR-FTIR spectroscopy. The FTIR spectra of pristine $\left(\mathrm{FW}_{200}\right)$ and model papers coated with nanofibrillated cellulose films are shown in Figure 7.

The bands in the range of $3340-3260 \mathrm{~cm}^{-1}$ and $2907-2859 \mathrm{~cm}^{-1}$ are attributed to characteristic O-H and $\mathrm{C}-\mathrm{H}$ stretching vibrations of hydroxyl and methyl/methylene groups, respectively, from cellulose and glycol [32]. The influence of the TEMPO-mediated oxidation that was applied as a chemical pretreatment for obtaining nanofibrillated cellulose dispersions, was observed by the appearance of the peak at $1600 \mathrm{~cm}^{-1}$ which originates from $\mathrm{C}=\mathrm{O}$ asymmetric stretching vibration of sodium carboxylates (COONa) [33]. Other signals observed in the spectra at $1639 \mathrm{~cm}^{-1}$ and in the range of $1160-1027 \mathrm{~cm}^{-1}$ are assigned to the $\mathrm{O}-\mathrm{H}$ bending of adsorbed water and the symmetric and asymmetric $\mathrm{C}-\mathrm{O}-\mathrm{C}, \mathrm{C}-\mathrm{C}$, and $\mathrm{C}-\mathrm{O}$ functional groups vibration, respectively, from nanofibrillated cellulose and additives [32]. The peak at $1424 \mathrm{~cm}^{-1}$, characteristic for bending $\mathrm{C}-\mathrm{H}$ vibration of a methyl group, is overlapped with $\mathrm{C}=\mathrm{O}$ symmetric carboxylate vibration and the carbonate ion $\left(\mathrm{CO}_{3}\right)^{2-}$ from $\mathrm{CaCO}_{3}$ [34]. Further, the peaks at $875 \mathrm{~cm}^{-1}$ and $709 \mathrm{~cm}^{-1}$ also indicate the presence of $\mathrm{CaCO}_{3}$, while the bond observed at $1001 \mathrm{~cm}^{-1}$ is assigned to $\mathrm{Al}-\mathrm{OH}$ groups vibration from $\mathrm{Al}(\mathrm{OH})_{3}$. Peaks at these wavenumbers are overlapped with out-of-plane bending vibration characteristic for methylene group present in cellulose [14,34-36]. The obtained results are in the agreement with our previous results obtained for lower grammage paper, i.e. $140 \mathrm{~g} / \mathrm{m}^{2}$ [14], in comparison with the paper grammage $200 \mathrm{~g} / \mathrm{m}^{2}$, used in this work. 

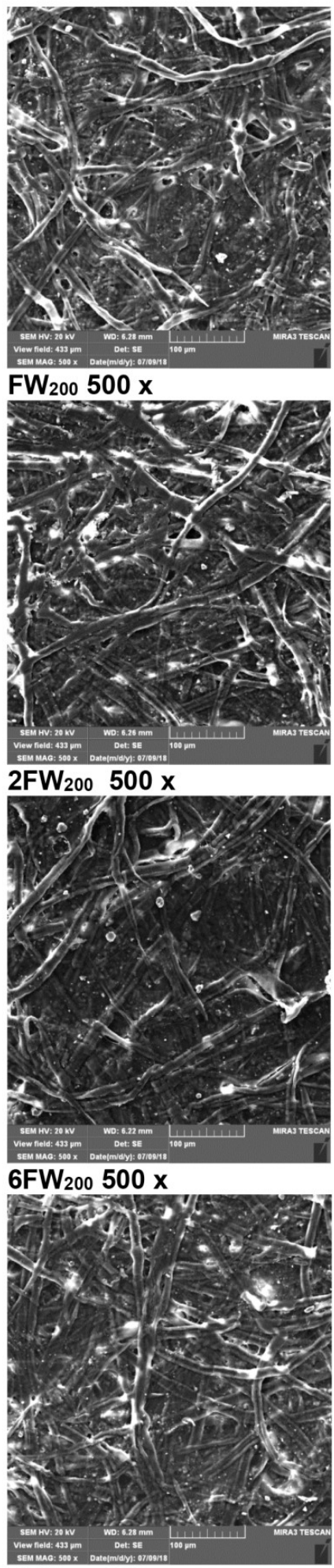

$7 F W_{200} 500 x$

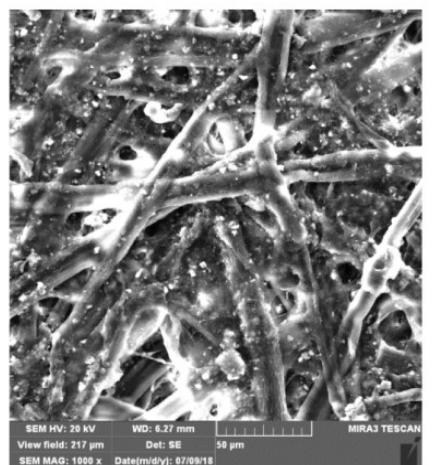

FW $2001000 x$

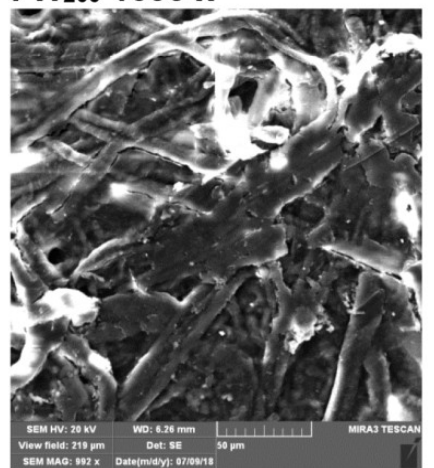

2FW $2001000 x$

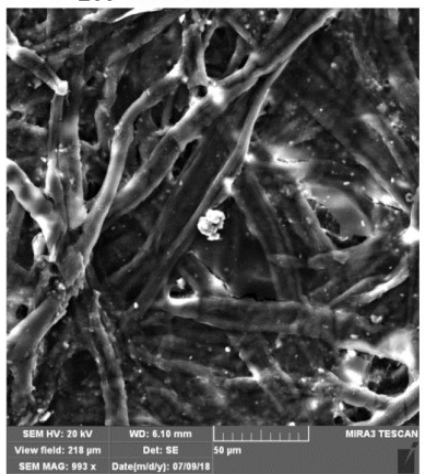

$6 W_{200} 1000 x$

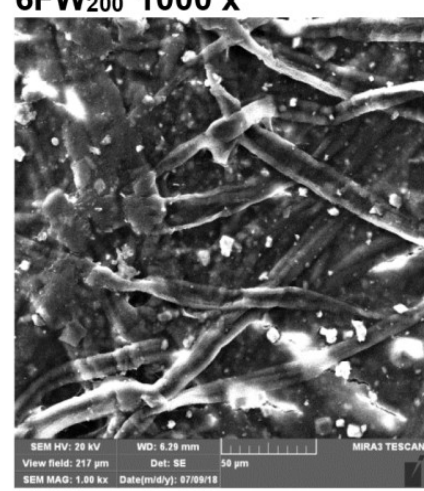

7FW200 $1000 x$

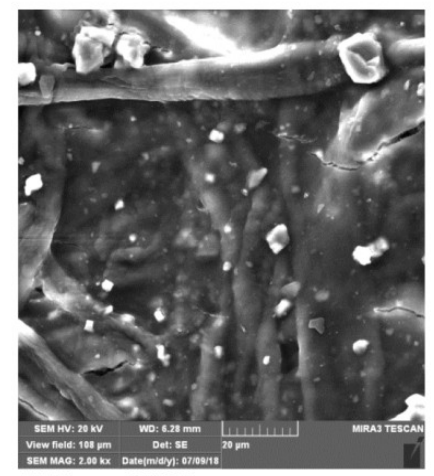

$\mathrm{FW}_{200} 2000$

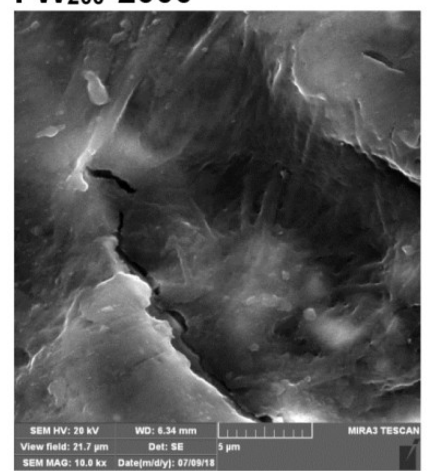

$2 F W_{200} 5000 x$

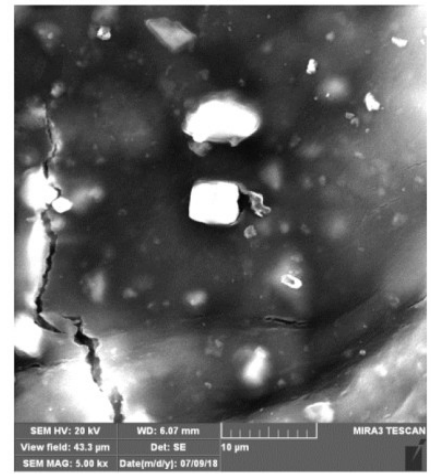

$6 \mathrm{FW}_{200} 5000 \mathrm{x}$

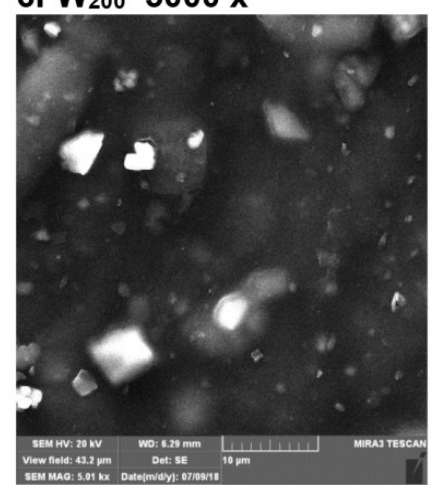

7FW $2005000 \times$

Figure 6. SEM microphotographs of the pristine model paper, $F W_{200}$, and model papers coated with the different nanofibrillated films based on cellulose (samples: $2 F W_{200}, 6 F W_{200}$, and $7 F W_{200}$ ) under different magnification

Slika 6. SEM mikrofotografije nemodifikovanog model papira $F W_{200}$ i model papira oslojenih nanoceluloznim filmovima različitog sastava (uzorci $2 F W_{200}, 6 F W_{200}$, and $7 F W_{200}$ ), snimljene pri različitim uvećanjima 

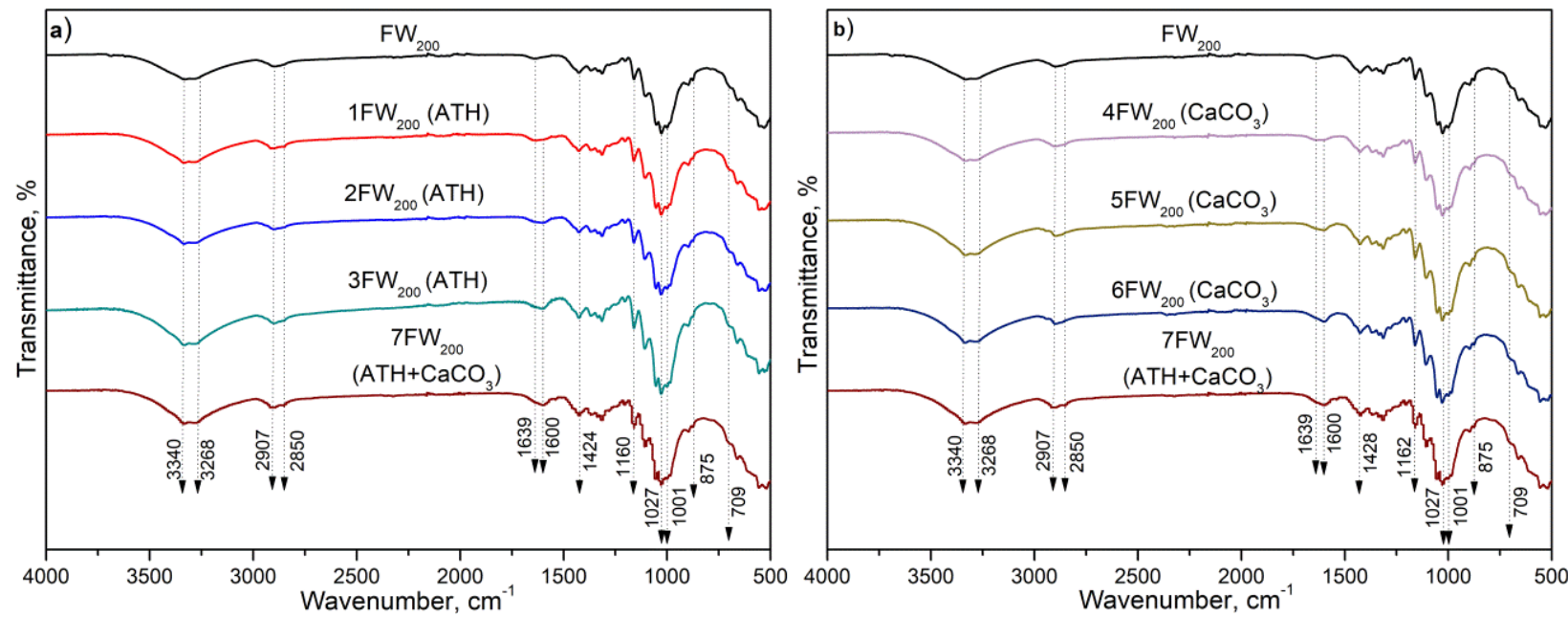

Figure 7. FTIR spectrum of pristine $\left(F W_{200}\right)$ and model papers coated with nanofibrillated cellulose films, with fillers: (a) $\mathrm{Al}(\mathrm{OH})_{3}-\mathrm{ATH}$ and (b) $\mathrm{CaCO}_{3}$

Slika 7. FTIR spektri nemodifikovanog model papira $\left(F W_{200}\right)$ i model papira oslojenih nanoceluloznim filmovima različitog sastava, sa puniocima: (a) $\mathrm{Al}(\mathrm{OH})_{3}-\mathrm{ATH}$ and (b) $\mathrm{CaCO}_{3}$

\section{CONCLUSION}

The results obtained in this study showed that nanofibrillated films, based on TEMPO-oxidized cotton linters, can be successfully applied for the reduction of the hydrophilic properties of paper. This is useful for artworks and documents that are stored in libraries and archives since the paper is vulnerable to humidity and water sorption. It was observed that in the case of application of dispersion 2 (1\% NFC + ATH + glycol + TOC), the best reduction in the sorption properties was achieved. The application of nanofibrillated cellulose films for the decrease in water absorptiveness does not cause changes in the optical properties and morphology of the paper surface, which is important for documents and artworks on paper from a practical point of view.

\section{Acknowledgment}

This work was supported by the Ministry of Education, Science and Technological Development of the Republic of Serbia (Contract No. 451-03-9/2021-14/200135 and 451-03-9/202114/200287). The authors thank the company "Dunav" a.d., Grocka, Belgrade, for providing the measurements of optical properties of paper.

\section{REFERENCES}

[1] U.Vohrer, I.Trick, J.Bernhardt, C.Oehr, H.Brunner (2001) Plasma treatment-an increasing technology for paper restoration?, Surface and Coatings Technology, 142-144, 1069-1073.

[2] F.Jiang, Y.Yang, J.Weng, X.Zhang (2016) Layer-byLayer Self-Assembly for Reinforcement of Aged Papers, Industrial and Engineering Chemistry Research, 55 (40), 10544-10554.
[3] M.He, B.-U.Cho, J.M.Won (2016) Effect of precipitated calcium carbonate-Cellulose nanofibrils composite filler on paper properties, Carbohydrate Polymers, 136, 820-825.

[4] L.Völkel, K.Ahn, U.Hähner, W.Gindl-Altmutter, A. Potthast (2017) Nano meets the sheet: adhesivefree application of nanocellulosic suspensions in paper conservation, Heritage Science, 5(1), 23-30.

[5] G.Banik, I.Brückle (2011) Paper and Water, A Guide for Conservators Principle. Oxford: Elsevier Publishers, Butterworth-Heinemann imprint.

[6] H.A.Carter (1996) The Chemistry of Paper Preservation Part 3. The Strengthening of Paper, Journal of Chemical Education, 73(12), 1160-1167.

[7] F.W.Brodin, W.Gregersen, K.Syverud (2014) Cellulose nanofibrils: Challenges and possibilities as a paper additive or coating material - A review, Nordic Pulp and Paper Research Journal, 29(1), 156-166.

[8] T.Taipale, M.Österberg, A.Nykänen, J. Ruokolainen, J.Laine (2010) Effect of microfibrillated cellulose and fines on the drainage of kraft pulp suspension and paper strength, Cellulose, 17( 5), 1005-1020.

[9] K.Isko Kajanto (2012) The potential use of microand nano fibrillated cellulose as a reinforcing element in paper and board based packaging, TAPPI International Conference on nanotechnology for renewable materials, 2(6), 42-48.

[10] A.E.Hassan, L.M.Hassan, K.Oksman (2011) Improving bagasse pulp paper sheet properties with microfibrilated cellulose isolated xylanase-treated bagasse, Wood Fiber Science, 42, 979-982.

[11] C.H.M.Camargos, J. C.D.Figueiredo, F.V. Pereira (2017) Cellulose nanocrystal-based composite for restoration of lacunae on damaged documents and artworks on paper, Journal of Cultural Heritage, 23, 170-175. 
[12] C.H.M.Camargos, J.C.D.Figueiredo, F.V.Pereira (2016) Nanocellulose for conservation and restoration of graphic documents, Experimental evidence p. 14

[13] V.F.Pereira (2016) Nanocellulose-based composites for conservation and restoration of cultural heritage on paper: Comparative studies between traditional and innovative methods (Conference paper), TAPPI international conference on nanotechnology for renewable materials, p. 348365 .

[14] J.Milanovic, T.Lazic, I.Zivkovic, M.Vuksanovic, M. Milosevic, M.Kostic (2020) The Effect of Nanofibrillated Tempo-oxidized Cotton Linters on the Strength and Optical Properties of Paper, Journal of Natural Fibers, Published online: 24 December 2020, 10.1080/15440478.2020.1848742.

[15] M.Korica et al. (2018) Novel protein-repellent and antimicrobial polysaccharide multilayer thin films," Holzforschung, 73(1), 93-103.

[16] A.E.J. de Nooy, A.C.Besemer, H. van Bekkum (2010) Highly selective tempo mediated oxidation of primary alcohol groups in polysaccharides, Recueil des Travaux Chimiques des Pays-Bas, 113(3), 165166.

[17] T.Choukri, V.Michel (2000) TEMPO-oxidation of cellulose: Synthesis andcharacterisation of polyglucuronans, Cellulose, 7, 177-188.

[18] T.Saito, I.Shibata, A.Isogai, N.Suguri, N.Sumikawa (2005) Distribution of carboxylate groups introduced into cotton linters by the TEMPO-mediated oxidation, Carbohydrate Polymers, 61(4), 414-419.

[19] P.S.Chang, J.F.Robyt (1996) Oxidation of Primary Alcohol Groups of Naturally Occurring Polysaccharides with 2,2,6,6-Tetramethyl-1Piperidine Oxoammonium Ion, Journal of Carbohydrate Chemistry, 15(7), 819-830.

[20] A.Isogai, T.Saito, H.Fukuzumi (2011) TEMPOoxidized cellulose nanofibers, Nanoscale, 3(1), 71 85.

[21] L.Jin, W.Yanwei, X.Qinghua, Y.Wenrun, C Zhengliang (2014) Cellulose nanofibers prepared from TEMPO-oxidation of kraft pulp and its flocculation effect on kaolin clay, Journal of Applied Polymer Science, 131(12), 40450.

[22] C.Honorato, V.Kumar, J.Liu, H.Koivula, C.Xu, M. Toivakka (2015) Transparent nanocellulose-pigment composite films, Journal of Materials Science, 50 (22), 7343-7352.

[23] B. Li et al. (2015) Cellulose nanocrystals prepared via formic acid hydrolysis followed by TEMPOmediated oxidation, Carbohydrate Polymers, 133, 605-612.

[24] X.Qinghua, L.Weigong, C.Zhengliang, Y.Gao, Q. Menghua (2014) TEMPO/NaBr/NaClO-Mediated
Surface Oxidation of Nanocrystalline Cellulose and Its Microparticulate RetentionSystem with Cationic Polyacrylamide, BioResources, 9(1), 994-1006.

[25] S.J.Eichhorn et al. (2010) Review: current international research into cellulose nanofibres and nanocomposites, Journal of Materials Science, 45 (1), 1-33.

[26] T.Saito, A.Isogai (2004) TEMPO-Mediated Oxidation of Native Cellulose. The Effect of Oxidation Conditions on Chemical and Crystal Structures of the Water-Insoluble Fractions, Biomacromolecules, 5(5), 1983-1989.

[27] J.Praskalo, M.Kostic, A.Potthast, G.Popov, B.Pejic, P. Skundric (2009) Sorption properties of TEMPOoxidized natural and man-made cellulose fibers, Carbohydrate Polymers, 77(4), 791-798.

[28] J.Z.Milanovic, P.Milanovic, R.Kragic, M.Kostic (2018) "Do-lt-Yourself" reliable pH-stat device by using open-source software, inexpensive hardware and available laboratory equipment, PLoS One, 13 (3), e0193744.

[29] Au.Stadler, D.Sage, D.Shape: Analysis, http://bigwww.epfl.ch/demo/dropanalysis/, 01.03.2021.

[30] A.F.Stalder, T.Melchior, M.Müller, D.Sage, T.Blu, M. Unser (2010) Low-bond axisymmetric drop shape analysis for surface tension and contact angle measurements of sessile drops, Colloids and Surfaces A: Physicochemical and Engineering Aspects, 364(1-3), 72-81.

[31] J.Shen, Z.Song, X.Qian, F.Yang (2010) Carboxymethyl cellulose/alum modified precipitated calcium carbonate fillers: Preparation and their use in papermaking, Carbohydrate Polymers, 81(3), 545-553.

[32] C.Chung, M.Lee, E.Choe (2004) Characterization of cotton fabric scouring by FT-IR ATR spectroscopy," Carbohydrate Polymers, 58 (4), 417-420.

[33] Y.Jin, K.J.Edler, F.Marken, J.L.Scott (2014) Voltammetric optimisation of TEMPO-mediated oxidations at cellulose fabric, Green Chemistry, 16 (6), 3322-3327.

[34] K.Castro, M.Pérez, M.D.Rodríguez-Laso, J.M. Madariaga (2003) "Peer Reviewed: FTIR Spectra Database of Inorganic Art Materials," Anal. Chem., 75(9), $214-221$.

[35] V.Hospodarova, E.Singovszka, N.Stevulova (2018) Characterization of Cellulosic Fibers by FTIR Spectroscopy for Their Further Implementation to Building Materials, American Journal of Analytical Chemistry, 9(6), 303-310.

[36] B.Yuan et al. (2016) Transparent and flame retardant cellulose/aluminum hydroxide nanocomposite aerogels, Science China Chemistry, 59(10), 1335-1341. 


\title{
IZVOD
}

\section{SMANJENJE SPOSOBNOSTI UPIJANJA VODE PAPIRA OSLOJENIH FILMOVIMA NA BAZI NANOFIBRILISANE CELULOZE}

\begin{abstract}
Nanofibrilisani filmovi na bazi TEMPO-oksidisanog pamučnog lintersa upotrebljeni su za smanjenje hidrofilnih svojstava papira. U tu svrhu su vodene disperzije nanofibrilisane celuloze različitog sastava: 1 i 3\% nanofibrilisane celuloze, do $13 \% \mathrm{CaCO}_{3}$ i/ili $\mathrm{Al}(\mathrm{OH})_{3}$, do $20 \%$ propan-1,2diol (glikol) $i$ do 21\% TEMPO-oksidisanih vlakana pamuka, nanošene na model papire, bez dodatka adheziva. Polazni i modifikovani model papiri sa oslojenim filmovima na bazi nanofibrilisane celuloze karakterisani su sa aspekta sposobnosti upijanja vode po COBB metodi $i$ određen je ugao kvašenja. Izgled i hemijski sastav površine papira karakterisani su skenirajućom elektronskom mikroskopijom (SEM) i infracrvenom spektroskopijom sa Furijeovom transformacijom (ATR-FTIR). Pored toga, primenom odgovarajućih standarda određena su optička svojstva polaznog i modifikovanih papira (CIE lab koordinate, refleksija, CIE stepen beline). Zavisno od sastava disperzija, svi model papiri pokazali su određeno smanjenje sposobnosti upijanja vode, bez promena optičkih svojstava i morfologije površine papira u odnosu na nemodifikovani papir.
\end{abstract}

Klučne reči: Nanofibrilisani celulozni filmovi, TEMPO-oksidisana celuloza, papir, sposobnost upijanja vode, ugao kvašenja, optička svojstva, morfologija površine.

Naučni rad

Rad primljen: 05. 04. 2021.

Rad prihvaćen: 04. 06. 2021.

Rad je dostupan na sajtu: www.idk.org.rs/casopis

(C) 2021 Authors. Published by Engineering Society for Corrosion. This article is an open access article distributed under the terms and conditions of the Creative Commons Attribution 4.0 International license (https://creativecommons.org/licenses/by/4.0/) 